
carotenoids, vitamins and minerals in wild mustard collected in native areas. Horticultura Brasileira 36: 059-065. DOI - http://dx.doi.org/10.1590/ S0102-053620180110

\title{
Chemical composition, carotenoids, vitamins and minerals in wild mustard collected in native areas
}

\author{
Galdino X Paula Filho'; Tibério F Barreira²; Ricardo HS Santos ${ }^{3}$; Silvia E Priore ${ }^{3}$; Ceres M Della Lucia ${ }^{3}$; \\ Helena M Pinheiro-Sant'Ana ${ }^{3}$
}

${ }^{1}$ UNIFAP, Mazagão-AP, Brazil; galdinoxpf@gmail.com; ${ }^{2}$ Universidade Estadual do Norte Fluminense (UENF), Campos dos GoytacazesRJ, Brazil; tiberiofbarreira@gmail.com; ㄱniversidade Federal de Viçosa (UFV), Viçosa-MG, Brazil; rsantos@ufv.br; sepriore@ufv.br; ceresnut@yahoo.com.br; helena.santana@ufv.br

\begin{abstract}
Wild mustard plant (Sinapis arvensis), Brassicaceae, is a wild vegetable found in forest area, domestic orchards and it is consumed by rural population. This study aimed to evaluate chemical composition (moisture, total dietary fiber, lipids, proteins, ash, carbohydrates and total energetic value), concentration of carotenoids, vitamins $(\mathrm{C}$ and $\mathrm{E})$ and minerals $(\mathrm{K}, \mathrm{Ca}, \mathrm{Mg}, \mathrm{Cu}, \mathrm{Fe}$, $\mathrm{Zn}, \mathrm{Mn}, \mathrm{Na}, \mathrm{Cr}$, Se and Mo) and the contribution by this vegetable to the recommendations of daily consumption of nutrients for adult individuals. Concentrations of provitamin A (252.21 RAE/100 g), Se $(0.04 \mathrm{mg} / 100 \mathrm{~g})$ and Fe $(5.91 \mathrm{mg} / 100 \mathrm{~g})$ stood out, in which this vegetable was considered as an excellent source for these nutrients. In addition, wild mustard was considered a good source of K (435.65 $\mathrm{mg} / 100 \mathrm{~g}), \mathrm{Ca}(123.25 \mathrm{mg} / 100 \mathrm{~g})$ and $\mathrm{Mn}(0.40 \mathrm{mg} / 100 \mathrm{~g})$ and source of Total Dietary Fiber (TDF) $(3.20 \mathrm{mg} / 100 \mathrm{~g}), \mathrm{Mg}(26.82 \mathrm{mg} / 100$ g) and $\mathrm{Cu}(0.07 \mathrm{mg} / 100 \mathrm{~g})$. Wild mustard stood out as source, good source or excellent source of the evaluated nutrients, and they may contribute to reduce nutritional deficiency of those nutrients in the populations living in the region where this vegetable occurs.
\end{abstract}

Keywords: Sinapis arvensis, unconventional vegetables, nutritional value, nutrients.

\section{RESUMO}

Composição química, carotenoides, vitaminas e minerais em mostarda silvestre coletada em ambiente silvestre

Plantas de mostarda silvestre (Sinapis arvensis), Brassicaceae, é uma hortaliça silvestre encontrada em área de florestas, pomares caseiros e consumida por populações rurais. O objetivo do presente estudo foi investigar a composição química (umidade, fibra alimentar total, lipídios, proteínas, cinzas, carboidratos e o valor energético total), a concentração de carotenoides, vitaminas (C e E), minerais $(\mathrm{K}, \mathrm{Ca}, \mathrm{Mg}, \mathrm{Cu}, \mathrm{Fe}, \mathrm{Zn}, \mathrm{Mn}, \mathrm{Na}, \mathrm{Cr}, \mathrm{Se}$ e $\mathrm{Mo}$ ) e a contribuição desta hortaliça para as recomendações da ingestão diária de nutrientes para indivíduos adultos. Destacaram-se concentrações de provitamina A (252,21 RAE / $100 \mathrm{~g}), \mathrm{Se}(0,04 \mathrm{mg} / 100 \mathrm{~g})$ e Fe $(5,91 \mathrm{mg} / 100 \mathrm{~g})$, sendo a hortaliça considerada excelente fonte desses nutrientes. Ainda, a mostarda silvestre foi considerada boa fonte de K $(435,65 \mathrm{mg} / 100$ g), Ca $(123,25 \mathrm{mg} / 100 \mathrm{~g})$ e $\mathrm{Mn}(0,40 \mathrm{mg} / 100 \mathrm{~g})$ e fonte de Fibra Alimentar Total (FAT) $(3,20 \mathrm{mg} / 100 \mathrm{~g}), \mathrm{Mg}(26,82 \mathrm{mg} / 100 \mathrm{~g})$ e Cu $(0,07 \mathrm{mg} / 100 \mathrm{~g})$. Em conclusão, a mostarda silvestre destacou-se como fonte, boa fonte ou excelente fonte dos nutrientes avaliados, e pode contribuir para diminuir a carência nutricional destes nutrientes nas populações residentes na região de ocorrência desta hortaliça.

Palavras-chave: Sinapis arvensis, hortaliça não convencional, valor nutricional, nutrientes.

\section{Received on October 20, 2016; accepted on June 15, 2017}

$\mathrm{T}_{3}$ he Brassicaceae family comprises 3,700 species distributed in 338 genera. One of these is Sinapis arvensis, known as mustard plant, field mustard, wild mustard and charlock. Native of Europe, it is also found in West Asia, Iran, North Africa and all over America ( $\operatorname{Rad}$ et al., 2013.). In several regions in the world, this species is used as forage for cattle feed, human food and as a medicinal plant (Bendimerad et al., 2007). In Brazil, its largest occurrence is in the Atlantic Forest and it is used for cooking, especially in rural areas (Barreira et al., 2015).
Worldwide this species is considered as a weed and it is frequent in many crops. There is information in the literature that pointing this species as invasive and recommend its control, including through the use of herbicides (Naderi \& Ghadiri, 2011). In Brazil, normative instructions and government resolutions, in addition to official research agencies classify this species as weed plant as well.

There are records on the use of wild mustard for cooking in some ethnobotanical studies, which show gradual replacement of this species by conventional food. Consumption of this plant and other native species occurs mainly by rural populations, whose practice is related to ethnobotanical knowledge and eating habits passed down from generation to generation ( $\mathrm{Di}$ Novella et al., 2013). The consumption of native plants by rural populations is considered of high importance. The access to these foods contributes to strategies of food sovereignty and security of these individuals (Krohn et al., 2015). Moreover, native species present several functional properties since they are important sources of 
nutrients, thereby providing benefits to human health (Paula Filho et al., 2015).

Although wild mustard is widely consumed by rural populations in the Brazilian Atlantic Forest and in other regions of the planet, studies on the concentration of nutrients in this species as well as their contribution to the intake of nutrients by the human body are not found. Thus, the objective of this study was to investigate the chemical composition and carotenoid concentrations, vitamins and minerals in wild mustard samples collected from wild environments and consumed by rural populations.

\section{MATERIAL AND METHODS}

\section{Plant material}

Sample collection was realized in December 2012, in Viçosa, state of Minas Gerais, Brazil. Samples were collected from the rural area: Buieié (2042'44"'S, 4249'59' W), Córrego

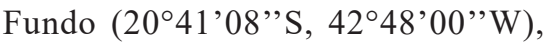

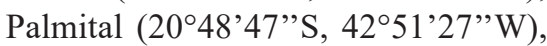
São José do Triunfo $\left(20^{\circ} 45^{\prime} 20^{\prime \prime}\right.$, $\left.42^{\circ} 49^{\prime} 25^{\prime \prime} \mathrm{W}\right)$ and Violeira $\left(20^{\circ} 44^{\prime} 05^{\prime \prime} \mathrm{S}\right.$, $42^{\circ} 51^{\prime} 27^{\prime}$ 'W), which characterized the experiment replicates. In each replicate, approximately $0.8 \mathrm{~kg}$ of fresh vegetable was obtained from twelve different plants, at least.

The samples were transported to the Vitamins Analysis Laboratory, Department of Nutrition and Health (DNS), of the Federal University of Viçosa (UFV) in polystyrene boxes, up to two hours after collection. Samples were washed in tap water to remove dirt; later, the leaves were manually separated from the other parts of the plant and then homogenized in domestic food processor (Philips, RI 7625, Brazil), packed in polyethylene bags, wrapped in foil and stored in a freezer $\left(-18 \pm 1^{\circ} \mathrm{C}\right)$, to perform the analyzes, which occurred within 72 hours.

\section{Chemical analyses}

Chemical analyzes were performed in three replicates in the laboratories of Food Analysis and Vitamin Analysis of DNS/UFV. Moisture was analyzed by means of gravimetry after drying in an oven (SP Labor, SP 200, Brazil) at $105^{\circ} \mathrm{C}$; ashes by gravimetry after drying in a muffle (Quimis, 318 , Brazil) at $550^{\circ} \mathrm{C}$; protein by the micro-Kjeldahl method (AOAC, 2010); lipid by gravimetry after extraction in ethyl ether using Soxhlet apparatus and total dietary fiber (TDF) by non-enzymatic gravimetry (AOAC, 2010). The carbohydrates were calculated by difference using the following equation:

Carbohydrate $=[100-\%$ moisture $\%$ lipids - $\%$ protein - $\%$ TDF - $\%$ ash]

Energy value was estimated considering the conversion factors of 4 $\mathrm{kcal} \mathrm{g}^{-1}$ for protein or carbohydrate and $9 \mathrm{kcal} \mathrm{g}^{-1}$ for lipids (Frary \& Johnson, 2005).

\section{Extraction and analysis of carotenoids and vitamins}

During collection, extraction and analysis, samples were protected from light, oxygen and heat, to prevent loss of carotenoids and vitamins. For the extraction of carotenoids and vitamins, the following reagents with purity degree were used for analysis: acetone, petroleum ether and glacial acetic acid (Vetec, Brazil). For analysis of compounds, the following High Efficiency Liquid Chromatography (HPLC) degree reagents were used: hexane, isopropanol, ethyl acetate, methanol and acetonitrile (Tedia, Brazil).

The analysis of carotenoids and vitamin $C$ were carried out in system HPLC (Shimadzu SCL 10AT VP, Japan) composed of a high-pressure pump (LC 10AT VP); automatic injector with "loop" $50 \mu \mathrm{L}$ (SIL-10AF); diode array detector (DAD) (SPD-M10A). For analysis of vitamin E, HPLC system (Shimadzu, SCL 10AD VP, Japan) composed of high-pressure pump with valve for low pressure quaternary gradient (LC 10AD VP) was used; automatic injector with "loop" of 50 $\mu \mathrm{L}$ (SIL-10AF); fluorescence detector (RF-10A XL).

\section{Carotenoids}

The occurrence and concentration of $\alpha$-carotene, $\beta$-carotene and $\beta$-cryptoxanthin was investigated in the samples. The carotenoids were extracted in acetone and transferred to petroleum ether (Rodriguez-Amaya et al., 1976). The chromatographic conditions used were as follows: HPLC-DAD system, Phenomenex Gemini chromatography column RP-18 (250 x $4.6 \mathrm{~mm}, 5 \mu \mathrm{m}$ i.d.) equipped with a Phenomenex guard column ODS (C18) (4 mm x $3 \mathrm{~mm}$ ); mobile phase composed of methanol: ethyl acetate: acetonitrile (70:20:10, $\mathrm{v}: \mathrm{v}: \mathrm{v})$ and mobile phase flow rate of $1.7 \mathrm{~mL} \mathrm{~min}^{-1}$. The running time was 12 minutes and the chromatograms were obtained at $450 \mathrm{~nm}$ (Figure 1). The standards of $\alpha$-carotene and $\beta$-carotene were isolated from concentrated carrot extract; $\beta$-cryptoxanthin and lycopene were isolated from extracts of papaya (Carica papaya), tomato (Solanum lycopersicum), respectively, by open column chromatography (RodriguezAmaya, 1989).

Concentration of vitamin A was calculated considering that 1 Retinol Activity Equivalent (RAE) corresponds to $1 \mu \mathrm{g}$ of retinol; $12 \mu \mathrm{g}$ of $\beta$-carotene; $24 \mu \mathrm{g}$ of other pro-vitamin A carotenoids (IOM, 2011).

\section{Vitamin C}

Occurrence and concentration of ascorbic acid (AA) and dehydroascorbic acid (ADA) were investigated in the samples according to Campos et al. (2009). Vitamin C was extracted in buffer solution (metaphosphoric acid at $3 \%$, acetic acid at $8 \%$, sulfuric acid $0.3 \mathrm{~N}$ and $1 \mathrm{mM}$ EDTA). ADA was converted to AA by using dithiothreitol, while for the analysis of ascorbic acid, chromatographic conditions were used in the same HPLC system used for carotenoids: RP-18 column (Lichrospher $100,250 \times 4 \mathrm{~mm}, 4 \mu \mathrm{mi} . d$.) equipped with a guard column (Phenomenex ODS column, $4 \mathrm{~mm} \times 3 \mathrm{~mm}$ ); mobile phase comprised of ultrapure water containing $1 \mathrm{mM}$ of $\mathrm{NaH}_{2} \mathrm{PO}_{4}, 1 \mathrm{mM}$ of EDTA and $\mathrm{pH}$ adjusted to 3.0 with $\mathrm{H}_{3} \mathrm{PO}_{4}$; flow

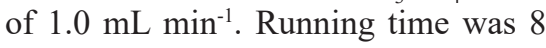
minutes and the chromatograms were obtained at $245 \mathrm{~nm}$. Concentration of $\mathrm{ADA}$ was calculated using the equation:

Concentration of $\mathrm{ADA}=\mathrm{AA}$ 
concentration after the conversion - AA concentration before conversion

The standard of L-Ascorbic acid was purchased from Sigma-Aldrich (Germany).

\section{Vitamin $E$}

Occurrence and concentration of the eight compounds of vitamin E $(\alpha-, \beta-, \gamma-$ and $\delta$-tocopherols and tocotrienols) were investigated in the samples. The extraction was done using solution of hexane: ethyl acetate (85:15, v:v) containing $0.05 \%$ butylated hydroxytoluene, and anhydrous sodium sulfate. For the analysis, the following chromatographic conditions were used: HPLC system; fluorescence detector $(290 \mathrm{~nm}$ excitation and 330 nm emission); LiChrosorb column (Si60 Phenomenex $250 \times 4 \mathrm{~mm}, 5$ $\mu \mathrm{m})$, provided with guard column (Phenomenex Si100, $4 \mathrm{~mm} \times 3 \mathrm{~mm}$ ); mobile phase - hexane: isopropanol: glacial acetic acid (98.9: 0.6: 0.5 $\mathrm{v} / \mathrm{v} / \mathrm{v}$ ); mobile phase flow: $1.0 \mathrm{~mL} / \mathrm{min}$ (Pinheiro-Sant'Ana et al., 2011).

The standards of vitamin E ( $\alpha-, \beta-$, $\gamma$ - and $\delta$-tocopherols and tocotrienols) were purchased from Calbiochem ${ }^{\circledR}$, EMD Biosciences, Inc. (USA).

\section{Identification and quantification of carotenoids and vitamins}

Compounds were identified by comparing the retention times of peaks obtained for the standards and samples analyzed under the same conditions. In addition, AA and carotenoids were identified by comparing the absorption spectra of peaks of interest in the samples and the standards, using DAD, and compounds of the vitamin E were identified by co-chromatography.

The compounds identified in samples of wild mustard were quantified using analytic curves and regression equations constructed by injection, in duplicate, of six different concentrations of standard solutions. A linear correlation was performed between the peak areas and concentrations of each compound.

\section{Determination of minerals}

The minerals ( $\mathrm{K}, \mathrm{Ca}, \mathrm{Mg}, \mathrm{Zn}$, $\mathrm{Mn}, \mathrm{Fe}, \mathrm{Cu}, \mathrm{In}, \mathrm{Cr}$, Se and Mo) were extracted with nitric acid and perchloric acid solutions $(4: 1, \mathrm{v}: \mathrm{v})$. A suspension of the sample was heated to $80^{\circ} \mathrm{C}$ followed by gradual increase up to $200^{\circ} \mathrm{C}$ until the extract had reached a crystalline coloration. After that, the extract was removed from the plate to cool at room temperature. Then, the crystalline extract was cooled and the volume was completed to $25 \mathrm{~mL}$ with deionized water (Gomes \& Oliveira, 2011). The obtained solution was used for reading of the concentration of minerals by Atomic Emission Spectrometry in Inductively Coupled Plasma (ICP-AES) (Perkin Elmer, Optima 8300).

Two multi-element standard solutions were prepared (MESS) in $100 \mathrm{~mL}$ flasks. Multi-element standard solution 1 was prepared for $\mathrm{Cr}$, Se, $\mathrm{Mo}, \mathrm{Zn}, \mathrm{Cu}, \mathrm{Fe}$ and Mn. Multi-element standard solution 2 was prepared for $\mathrm{Na}, \mathrm{Mg}, \mathrm{Ca}$ and $\mathrm{K}$. Finally, for each multi-element standard solution, the volume was completed to $50 \mathrm{~mL}$ with deionized water.

For quantification, analytical curves were plotted using standards of minerals, acquired from Vetec (Brasil) and Merck (Brazil). For the construction of analytical curves, increasing volumes of multi-element standard solution $1(0$ to $2 \mathrm{~mL}$ ) and multi-element standard solution 2 ( 0 to $20 \mathrm{~mL})$ were used, completing the volume to $50 \mathrm{~mL}$ with deionized water to construct the six points of the curve.

The samples were analyzed for concentrations of $\mathrm{Ca}, \mathrm{Fe}, \mathrm{Mg}, \mathrm{Mn}$, $\mathrm{Cu}, \mathrm{Zn}, \mathrm{Se}, \mathrm{Mo}, \mathrm{Cr}, \mathrm{K}$ and Na. The respective wavelengths $(\mathrm{nm})$ used were: $317.93 ; 259.94 ; 285.21 ; 259.37$; $224.70 ; 213.86 ; 196.03 ; 202.03 ; 267.72$; 404.72 and 589.59. After the reading, the concentrations found in ppm (mg $\mathrm{L}^{-1}$ ) in the samples were converted into concentrations of minerals.

\section{Calculation of wild mustard potential as sources of nutrients}

The nutritional contribution potential was estimated based on the Recommended Dietary Allowance (RDA) for adult men at 19 to 30 years (IOM, 2011). The wild mustard portions were calculated according to the Food Guide for the Brazilian Population
(Brasil, 2008), in which a vegetable portion is equivalent to $30 \mathrm{kcal}$.

Wild mustard was classified as "source" of the nutrient when it presented potential to supply 5 to $10 \%$ of the Dietary Reference Intake (DRI); as "good source", from 10 to $20 \%$ of DRI and "excellent source" when it displayed the potential to attend more than $20 \%$ of DRI (Philippi, 2008).

\section{Experimental design and data statistical analysis}

A completely randomized design with five replicates for carotenoid and vitamin analysis, and three replicates for chemical analysis were used in this study. Descriptive statistics (mean, standard deviation and range of parameters) were used to present the results. To analyze linear regression and calculate the correlation coefficient $\left(\mathrm{R}^{2}\right)$, linearity range of analytical standards and the areas of the chromatographic peaks were used. Statistical analysis was performed using SAS software (Statistical Analysis System), version 9.2 (2008), licensed to the UFV.

\section{RESULTS AND DISCUSSION}

Samples of wild mustard evaluated in this study were collected in the wild environment; it is a native species that spreads spontaneously, and that according to Miller \& Gross (2011) may have high genetic variability. In this study, environmental factors (soil nutrients, radiation, moisture, water), which may interfere with the concentration of nutrients in vegetables was not controlled.

The lack of studies on chemical characterization and concentration of carotenoids, vitamins and minerals in wild mustard made it impossible to compare the data obtained in this study with other results. Moreover, similar studies with other species of the Sinapis genus were not found, which shows the importance and uniqueness of this work. However, it is noteworthy that wild mustard belongs to the same botanical family (Brassicaceae) in which there are other species of conventional vegetables 
with higher consumption demand, such as cabbage (Brassica oleracea var. capitata and kale (Brassica oleracea var. acephala), broccoli (Brassica oleracea var. italica) and turnip (Brassica napus).

\section{Chemical characterization}

Wild mustard showed high concentration of water $(91.68 \mathrm{~g} / 100 \mathrm{~g})$, however, it has a low concentration of lipid (0.85 g/100 g) and ash (0,98 g/100 g). Wild mustard plant showed similar nutritional value to other Brassica, as well as, moisture values found in this study are close to those found by Melo \& Faria (2014) for cabbage $(92.77 \mathrm{~g} / 100$ g) and broccoli $(91.53 \mathrm{~g} / 100 \mathrm{~g})$ in a study conducted in Minas Gerais, with vegetables collected in street markets.

The results based on RDA basis for adult men at 19 to 30 years old, showed that wild mustard may contribute with $9.52 \%$ of RDA of FAT, being considered source of this nutrient. However, this vegetable was not considered source of protein and carbohydrates, as they may contribute with only $4.46 \%$ and 2.39 of RDA of these nutrients, respectively (Table 1).

Regarding the concentration of TDF in Brassica, the Brazilian Table of Food Composition (Unicamp, 2011) shows similar results to the present study; however, it is highlighted that these results were obtained by gravimetric enzymatic method, while in the present study, the analysis was performed by non-enzymatic gravimetric method. These methods differ in their methods of analysis, since the non-enzymatic gravimetric method is used for determining dietary fiber in foods with low starch content, such as fruit and vegetables, whereas the enzymatic gravimetric method is used for enzymatic digestion to remove nonfibrous components, allowing the quantification of dietary fiber residue by weighing, which may cause errors in the interpretation of the data. In this work, the studied vegetable was considered source of TDF, since it presented the potential to contribute with $9.52 \%$ of the RDA for adults at 19 to 30 years old. Thus, this vegetable makes an important contribution by providing TDF for the local population, since it occurs all over the Atlantic Forest biome (Barreira et al., 2015).

In researches on concentrations of lipids in some Brassicas such as cabbage $(10.4 \mathrm{~g} / 100 \mathrm{~g})$ and turnip $(0.10$ $\mathrm{g} / 100 \mathrm{~g}$ ) in the Brazilian Table of Food Composition (Unicamp, 2011); and broccoli (0.30 g/100 g) and cabbage $(0.05 \mathrm{~g} / 100 \mathrm{~g})$ researched by Melo \& Faria (2014), a difference was observed between these results and those of the present work. However, it is emphasized that it is necessary to consider that this species was collected in the wild environment, where they tend to present high genetic variability.

Protein concentrations found in this study are consistent with those of other brassicas (raw cauliflower: 1.9 g/100 g; raw purple cabbage: $1.9 \mathrm{~g} / 100$ $\mathrm{g})$, according to the Brazilian Table of
Food Composition (Unicamp, 2011). the same relationship was found to the concentration of ash (broccoli: $0.8 \mathrm{~g} / 100$ $\mathrm{g}$; raw purple cabbage: $0.7 \mathrm{~g} / 100 \mathrm{~g}$ ).

Melo \& Faria (2014) found concentrations of carbohydrate in cabbages collected in street markets $(3.02 \mathrm{~g} / 100 \mathrm{~g})$ similar to that found in this study.

\section{Carotenoids and vitamins}

The presence of $\alpha$-carotene was found $(0.34 \mathrm{mg} / 100 \mathrm{~g})$ and $\beta$-carotene $(2.91 \mathrm{mg} / 100 \mathrm{~g})$ in wild mustard samples. The sum of these two carotenoids was $3.25 \mathrm{mg} / 100 \mathrm{~g}$ and value of vitamin A found in this study was equal to 252.21 RAE/100 g. Vitamin C was not found in the samples (Table 2). Wild mustard was considered a source of vitamin A for adults at 19 to 30 years old, contributing

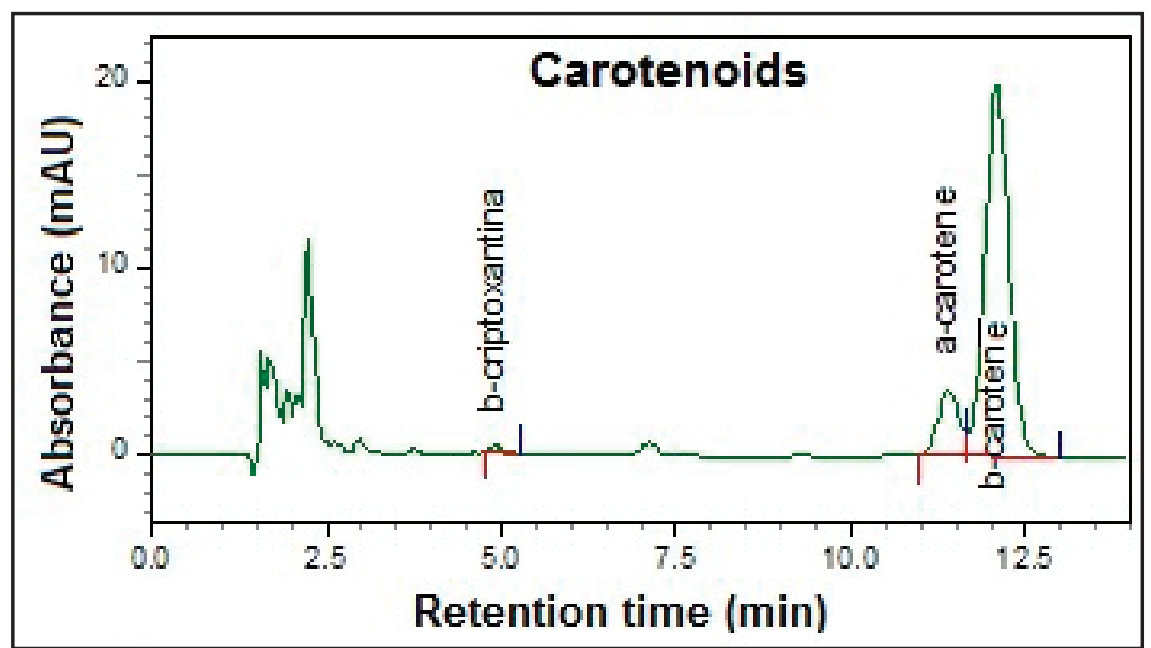

Figure 1. Chromatograms of carotenoid analyzes by HPLC in Sinapis arvensis samples. Viçosa, UFV, 2012/2013.

Table 1. Centesimal composition and total energy value of wild mustard and contribution percentage of fibers, proteins and carbohydrates in relation to those of Recommended Dietary Allowances (RDA). Viçosa, UFV, 2012/2013.

\begin{tabular}{lcc}
\hline Nutrients & Values & $\begin{array}{c}\text { Contribution for RDA } \\
(\%)\end{array}$ \\
\hline Moisture $(\mathrm{g} / 100 \mathrm{~g})$ & $91.68 \pm 3.19$ & \\
Total dietary fiber $(\mathrm{g} / 100 \mathrm{~g})$ & $3.20 \pm 0.09$ & 9.52 \\
Lipíds $(\mathrm{g} / 100 \mathrm{~g})$ & $0.85 \pm 0.02$ & 4.46 \\
Proteins $(\mathrm{g} / 100 \mathrm{~g})$ & $1.97 \pm 0.04$ & \\
Ash $(\mathrm{g} / 100 \mathrm{~g})$ & $0.98 \pm 0.01$ & 2.39 \\
Carbohydrates $(\mathrm{g} / 100 \mathrm{~g})$ & $2.75 \pm 0.42$ & \\
Total energetic value $(\mathrm{Kcal} / 100 \mathrm{~g})$ & $26.57 \pm 1.67$ & \\
\hline
\end{tabular}

Values expressed in dry matter; mean of three repetitions; data presented in: mean \pm standard deviation. *Calculated on the basis of Recommended Dietary Allowance (RDA) for adults at 19 and 30 years old (IOM, 2011); a portion of vegetable is $30 \mathrm{kcal}$ (BRASIL, 2008). 
with $31.7 \%$ of the RDA for these adults.

The predominant compound for vitamin $\mathrm{E}$ was $\alpha$-tocopherol (280.14 $\mathrm{mg} / 100 \mathrm{~g})$. In addition, $\beta$-tocopherol $(21.12 \mu \mathrm{g} / 100 \mathrm{~g}), \gamma$-tocopherol $(22.90$ $\mu \mathrm{g} / 100 \mathrm{~g})$ and $\delta$-tocotrienol $(24.45$ $\mu \mathrm{g} / 100 \mathrm{~g})$ were found. The total concentration of vitamin E was 348.61 $\mu \mathrm{g} / 100 \mathrm{~g}$ (Table 2). A portion of wild mustard may contribute only with $2.1 \%$ of the RDA for adults (Table 2).

According to Table 2, wild mustard

Table 2. Concentration and contribution (\%) in relation to Recommended Dietary Allowances (RDA) of carotenoids and vitamins in wild mustard. Viçosa, UFV, 2012/2013.

\begin{tabular}{|c|c|c|c|}
\hline Compounds & Values & $\%$ & $\begin{array}{l}\text { Contribution } \\
\text { for } \operatorname{RDA}(\%)\end{array}$ \\
\hline Value of vitamin A (RAE $\mu \mathrm{g} / 100 \mathrm{~g})$ & $252.21 \pm 2.34$ & 100 & 31.67 \\
\hline Carotenoids (mg/100 g) & $3.2 \pm 0.03$ & 100 & \\
\hline$\alpha$-carotene $(\mathrm{mg} / 100 \mathrm{~g})$ & $0.34 \pm 0.02$ & $10.46 \%$ & \\
\hline$\beta$-carotene $(\mathrm{mg} / 100 \mathrm{~g})$ & $2.91 \pm 0.05$ & $89.54 \%$ & \\
\hline$\beta$-cryptoxanthin (mg/100 g) & nd & -- & \\
\hline Total vitamin $\mathrm{C}(\mathrm{mg} / 100 \mathrm{~g})$ & nd & -- & nd \\
\hline Ascorbic acid (mg/100 g) & nd & -- & \\
\hline Dehydroascorbic acid (mg/100 g) & nd & -- & \\
\hline Total vitamin $\mathrm{E}(\mu \mathrm{g} / 100 \mathrm{~g})$ & $348.61 \pm 25.33$ & 100 & $2.11 *$ \\
\hline$\alpha$-tocopherol $(\mu \mathrm{g} / 100 \mathrm{~g})$ & $280.14 \pm 15.17$ & 80.36 & \\
\hline$\alpha$-tocotrienol $(\mu \mathrm{g} / 100 \mathrm{~g})$ & nd & -- & \\
\hline$\beta$-tocopherol ( $\mu \mathrm{g} / 100 \mathrm{~g})$ & $21.12 \pm 2.62$ & 6.06 & \\
\hline$\beta$-tocotrienol $(\mu \mathrm{g} / 100 \mathrm{~g})$ & nd & -- & \\
\hline$\gamma$-tocopherol $(\mu \mathrm{g} / 100 \mathrm{~g})$ & $22.90 \pm 3.42$ & 6.57 & \\
\hline$\gamma$-tocotrienol ( $\mu \mathrm{g} / 100 \mathrm{~g})$ & nd & -- & \\
\hline$\delta$-tocopherol $(\mu \mathrm{g} / 100 \mathrm{~g})$ & nd & -- & \\
\hline$\delta$-tocotrienol $(\mu \mathrm{g} / 100 \mathrm{~g})$ & $24.45 \pm 4.12$ & 7.01 & \\
\hline
\end{tabular}

Values expressed in fresh matter; mean of five repetitions; data presented in: mean \pm standard deviation. $\mathrm{nd}=$ not found; $*$ (calculated on the basis of $\alpha$-tocopherol).

Table 3. Concentration of minerals and contribution (\%) in relation to Recommended Dietary Allowances (RDA) in wild mustard. Viçosa, UFV, 2012/2013.

\begin{tabular}{lcc}
\hline Minerals & Values $(\mathbf{m g} / \mathbf{1 0 0} \mathbf{g})$ & Contribution for RDA $(\%)$ \\
\hline $\mathrm{K}$ & $435.65 \pm 11.47$ & 11.72 \\
$\mathrm{Ca}$ & $123.25 \pm 4.41$ & 13.93 \\
$\mathrm{Mg}$ & $26.82 \pm 3.89$ & 7.58 \\
$\mathrm{Cu}$ & $0.07 \pm 0.02$ & 8.79 \\
$\mathrm{Fe}$ & $5.91 \pm 1.18$ & 83.48 \\
$\mathrm{Zn}$ & $0.21 \pm 0.02$ & 2.16 \\
$\mathrm{Mn}$ & $0.4 \pm 0.01$ & 19.65 \\
$\mathrm{Na}$ & $3.06 \pm 0.49$ & 0.23 \\
$\mathrm{Cr}$ & nd & $\mathrm{nd}$ \\
$\mathrm{Se}$ & $0.04 \pm 0.01$ & 82.18 \\
$\mathrm{Mo}$ & nd & nd \\
\hline
\end{tabular}

$\overline{\text { Values expressed in dry matter; mean of three repetitions; data presented in: mean } \pm \text { standard }}$ deviation; $\mathrm{nd}=$ not found. plant shows a potential as an excellent source of vitamin A (252.21 RAE 100 $\mathrm{g})$, is a species of wide occurrence in the region where this study was carried out (Barreira et al., 2015), where a high prevalence of hipovitaminose A occurs in students in many municipalities (Santos et al., 2005).

In a study accomplished by Salvatore et al. (2005), these authors evaluated concentrations of $\beta$-carotene in two species of the genus Sinapis (S. incana and $S$. nigra) and found similar results to the present study being $3.03 \mathrm{mg} / 100$ $\mathrm{g}$ in $S$. incana and $3.7 \mathrm{mg} / 100 \mathrm{~g}$ in $S$. nigra. These same authors found concentrations of ascorbic acid in species of $S$. incana $(11.92 \mathrm{mg} / 100 \mathrm{~g})$ and $S$. nigra $(11.07 \mathrm{mg} / 100 \mathrm{~g})$, and of total vitamin C $(12.13 \mathrm{mg} / 100 \mathrm{~g}$ in $S$. incana and $11.16 \mathrm{mg} / 100 \mathrm{~g}$ in $S$. nigra), unlike the present study that did not find these compounds in S. arvensis. It is necessary to investigate tocopherols in species of Sinapis genus since there is little information on concentration of such vitamin in these species. There are studies in the literature on the investigation of tocopherols only in species of other botanical genus similar to Sinapis, for example with the Brassica genus, such as studies carried out with cauliflower, cabbage and broccoli (Kurilich et al., 1999; Chun et al., 2006), while this is the first study to analyze the concentration of tocopherols in $S$. arvensis. Although this vegetable is not source of vitamin $\mathrm{E}$ as it was found in this study, it may contribute with $2.11 \%$ of RDA.

Wild mustard was considered as source of vitamin A for adult individuals at 19 to 30 years old, contributing with $31.67 \%$ of RDA for those adults. For vitamin $\mathrm{E}$, although a portion of this vegetable gives $2.11 \%$ of RDA, it is not a source of this vitamin (Table 2).

\section{Minerals}

Among all minerals analyzed in this study, those with higher concentrations were K (435.65 mg/100 g), Ca (123.25 $\mathrm{mg} / 100 \mathrm{~g}), \mathrm{Mg}$ (26.82 mg/100 g), Fe $(5.91 \mathrm{mg} / 100 \mathrm{~g})$ and $\mathrm{Na}(3.06 \mathrm{mg} / 100$ g). According to the RDA for these minerals, wild mustard was considered excellent source of $\mathrm{Fe}$ and $\mathrm{Se}$; good 
source of $\mathrm{K}, \mathrm{Ca}$ and $\mathrm{Mn}$ and a source of $\mathrm{Mg}$ and $\mathrm{Cu}$ (Table 3).

Selenium is an important mineral in the formation of antioxidant enzymes being required in minute amounts. According to Ferreira et al. (2002), the concentration of selenium in food may vary according with content of this mineral present in the soil. The daily recommendation of this element for adults is $55 \mu \mathrm{g}$ (IOM, 2011). Finley (2006) reported absorption of 70-95\% of all forms of selenium in foods. $S$. arvensis presents as excellent source of this nutrient.

Wild mustard plant was considered an excellent source of iron, and it may contribute with $83.48 \%$ of the recommendations for the adults. However, further studies are needed to evaluate the bioavailability of this mineral in this vegetable. Iron deficiency is the most prevalent nutritional disturbance in the world (Umbelino \& Rossi, 2006), affecting specially children younger than four years old, lactants, pregnant women and women at fertile age (Baltussen et al., 2004). This is a source of concern since there are records in the literature on the occurrence of iron deficiency in Viçosa (Cavalcante et al., 2006; Miranda et al., 2006), especially in children.

For concentration of manganese, wild mustard plant was considered a good source of this mineral, which is an essential nutrient, playing an important role in the formation of bones, in the energy and protein metabolism, in cell protection on free radicals and in the formation of glucosamine.

Consumption of wild mustard plant may represent an important tool for reducing the risk of nutritional and food insecurity, especially of those farmers and their families, living in the region where the present study was performed.

This species presents good nutritional potential, especially in relation to TDF, value of vitamin $\mathrm{A}$, potassium, calcium, magnesium, copper, iron, manganese and selenium. Although this vegetable is not source of all nutrients, it is important to highlight that it is consumed as food complement, and not as main base of human food.

\section{ACKNOWLEDGMENTS}

This study was carried out with the support of National Council for Scientific and Technological Development (CNPq), Foundation for Research Support of the State of Minas Gerais (FAPEMIG), Foundation Arthur Bernardes (FUNARBE), Coordination for the Improvement of Higher Education Personnel (CAPES) and Graduate Program in Agroecology of the Federal University of Viçosa.

\section{REFERENCES}

AOAC. 2010. Official methods of analysis. (17 $7^{\text {th }}$ ed.). Washington: AOAC. 417p.

BALTUSSEN, R; KNAI, C; SHARAN, M. 2004. Iron fortification and iron supplementation are cost-effective interventions to reduce iron deficiency in four sub regions of the world. Journal of Nutrition 134: 2678-2684.

BARREIRA, TF; PAULA FILHO, GX; RODRIGUES, VCC; ANDRADE, FMC; SANTOS, RHS; PRIORE, SE; PINHEIROSANT'ANA, HM. 2015. Diversidade e equitabilidade de plantas alimentícias não convencionais na zona rural de Viçosa, Minas Gerais, Brasil. Revista Brasileira de Plantas Medicinais 17: 964-974.

BENDIMERAD, N; BENDIAB, SAT; BREME, K; FERNANDEZ, X. 2007. Essential oil composition of aerial parts of Sinapis arvensis L. from Algeria. Essential Oil Research Journal 19: 206-208.

BRASIL - Ministério da Saúde. 2008. Guia Alimentar para a População Brasileira. Brasília: Ministério da Saúde. 210p.

CAMPOS, FM; RIBEIRO, SMR; DELLA LUCIA, CM; PINHEIRO-SANT'ANA, HM; STRINGHETA, PC. 2009. Optimization of methodology to analyze ascorbic and dehydroascorbic acid in vegetables. Química Nova 32: 87-91.

CAVALCANTE, AAM; TINÔCO, ALA; COTTA, RMM; RIBEIRO, RCL; PEREIRA CAS; FRANCESCHINI, SCC. 2006. Consumo alimentar e estado nutricional de crianças atendidas em serviços públicos de saúde do município de Viçosa, Minas Gerais. Revista Nutrição 19: 321-330.

CHUN, J; LEE, J; YE, L; EXLER, J; EITENMILLER, RR. 2006. Tocopherol and tocotrienol contents of raw and processed fruits and vegetables in the United States diet. Journal of Food Composition and Analysis 19: 196-204.

DI NOVELLA, R; DI NOVELLA, N; DE MARTINO, L; MANCINI, E; DE FEO, V. 2013. Traditional plant use in the National Park of Cilento and Vallo di Diano, Campania, Southern, Italy. Journal of Ethnopharmacology 145: 328-342.

FERREIRA, KS; GOMES, JC; BELLATO, CR; JORDÃO, CP. 2002. Concentrações de selênio em alimentos consumidos no Brasil. Revista Panamericana de Salud Publica 11: 172-177.

FINLEY, JW. 2006. Bioavailability of selenium from foods. Nutrition Reviews 64: 146-152.

FRARY, CD; JOHNSON, RK. 2005. Energia. In: MAHAN, LK; ESCOTT-STUMP, S (orgs). Krause: alimentos, nutrição e dietoterapia. 5. ed. Rio de Janeiro: Rocca, p.20-34.

GOMES, JC; OLIVEIRA, GF. 2011. Fotometria de chama e espectrofotometria de absorção atômica. In: GOMES, JC; OLIVEIRA, GF (orgs). Análises físico-químicas de alimentos: Fotometria de Chama e Espectrofotometria de Absorção Atômica. 1ed.Viçosa: UFV, p.47-52.

IOM - Institute of Medicine. 2011. Dietary Reference Intakes (DRIs): vitamin a, vitamin $k$, arsenic, boron, cromium, copper, iodine, iron, manganese, molybdenium, nickel, silicon, vanadium and zinc. Washington: Institute of Medicine. 310p.

KROHN, E; JAMES, R; SEGREST, V; RECTOR, T; BRULE, A; RAMEY, B; CAMPBELL, E; HARVEY, M; HERNANDEZ, M; COOPER, V; SEYMOUR, SG; FERNANDES, R; GRINNELL, E. 2015. Restoring individual and community health: Northwest native plants and foods collective. Fourth World Journal 14: 17-19.

KURILICH, AC; TSAU, GJ; BROWN, A; HOWARD, L; KLEIN, BP; JEFFERY, EH; KUSHAD, M; WALLIG, MA; JUVIK, JA. 1999. Carotene, tocopherol, and ascorbate contents in subspecies of Brassica oleracea. Journal of Agricultural and Food Chemistry 47: 1576-1581.

MELO, CMT; FARIA, JV. 2014. Composition, phenolic compounds and antioxidant activity in conventional not edible part of six vegetables. Bioscience Journal 30: 93-100.

MILLER, AJ; GROSS, BL. 2011. From forest to field: perennial fruit crop domestication. American Journal of Botany 98: 1389-1414.

MIRANDA, AS; FRANCESCHINI, SCC; PRIORE, SE; EUCLYDES, MP; ARAÚJO, RMA; RIBEIRO, SMR; NETTO, MP; FONSECA, MM; ROCHA, DS; SILVA, DG; LIMA, NMM; MAFFIA, UCC. 2006. Anemia ferropriva e estado nutricional de crianças com idade de 12 a 60 meses do município de Viçosa, MG. Revista Nutrição 16: 163-169.

NADERI, R; GHADIRI, H. 2011. Competition of Wild Mustard (Sinapis arvensis L.) Densities with Rapeseed (Brassica napus L.) under different levels of nitrogen fertilizer. Journal of Agricultural Science Technology 13: 45-51.

PAULA FILHO, GX; BARREIRA, TF; PINHEIRO, SS; CARDOSO, LC; MARTINO, HSD; PINHEIRO-SANT'ANA,HM. 2015. 'Melão croá' (Sicana sphaerica Vell.) and 'maracujina' (Sicana odorifera Naud.): chemical composition, carotenoids, vitamins and minerals in native fruits from the Brazilian Atlantic forest. Fruits 70: 341-349.

PHILIPPI, ST. 2008. Pirâmide dos alimentos: fundamentos básicos da nutrição. $1^{\text {st }}$ ed. Barueri: Manole. 383p.

PINHEIRO-SANT'ANA, HM; GUINAZI, M; OLIVEIRA, DS; DELLA LUCIA, CM; REIS, BL; BRANDÃO, SCC.2011. Method for simultaneous analysis of eight vitamin $\mathrm{E}$ 
isomers in various foods by high performance liquid chromatography and fluorescence detection. Journal of Chromatography A 47: 8496-8502.

RAD, JS; ALFATEMI, MH; RAD, MS; SEN, DJ. 2013. Phytochemical and antimicrobial evaluation of the essential oils and antioxidant activity of aqueous extracts from flower and stem of Sinapis arvensis L. American Journal of Advanced Drug Delivery 1: 1-10.

RODRIGUEZ-AMAYA, DB. 1989. Critical review of provitamin A determination in plant foods. Journal of Micronutrient Analysis 5:
191-225.

RODRIGUEZ-AMAYA, DB; RAYMUNDO, LC; LEE, TC; SIMPSON, KL; CHICHESTER, CO. 1976. Carotenoid changes in ripening Momordica charantia. Annals of Botany 40: 615-624.

SALVATORE, S; PELLEGRINI, N; BRENNA, OV; DEL RIO, D; FRASCA, G; BRIGHENTI, F; TUMINO, R. 2005. Antioxidant characterization of some Sicilian edible wild greens. Journal of Agricultural and Food Chemistry 53: 9465-9471.

SANTOS, MA; REZENDE, EG; LAMOUNIER,
J.A; GALVÃO, MAM; BONOMO, E; LEITE, RC. 2005. Hipovitaminose A em escolares da zona rural de Minas Gerais. Revista Nutrição18: 331-339.

UMBELINO, DC; ROSSI, EA. 2006. Deficiência de ferro: consequências biológicas e propostas de prevenção. Revista de Ciências Farmacêuticas Básica e Aplicada 27: 103-112.

UNICAMP. 2011. Tabela Brasileira de Composição de Alimentos: TACO. $4^{\text {th }}$ ed. Campinas: UNICAMP/NEPA. 161p. 